\title{
MEDICAL POLICE. POLITICS AND POLICE: THE FATE OF JOHN ROBERTON
}

\author{
by
}

\author{
BRENDA M. WHITE*
}

IT is difficult to imagine a case more deserving of detailed historical analysis than that of John Roberton (1776-1840), a surgeon who practised as a specialist in the treatment of venereal disease in two European capitals ${ }^{1}$ yet is linked to a subject, medical police, which, on close examination, occupied a fraction of his known professional life. Despite his widely published popular works on venereal disease, Roberton's place in medical history is secured under public health by his authorship of one work, $A$ treatise on medical police, and on diet, regimen, $\& c{ }^{2}$ In the history of public health and social medicine, he usually forms a triptych with two other distinguished scholars associated with medical police: Johann Peter Frank, professor of medicine at Pavia and Vienna, author of $A$ complete system of medical polity, ${ }^{3}$ and Andrew Duncan, senior, professor of the institutes of medicine at Edinburgh, a mover in the foundation there of the first British chair of medical jurisprudence and medical police in 1807, and author of Heads of lectures on medical jurisprudence and medical police. ${ }^{4}$

Little has been written about Roberton's professional life, yet it should be of as much interest to the historian as his published work on medical police, because it offers an illustration of a medical entrepreneur who, though openly disclaimed by the medical establishments of Edinburgh and London, was nevertheless able to operate successfully on the lucrative fringes of medicine. With limited formal education, and lacking influential connexions, Roberton advanced himself as a specialist in venereal disease, deploying unorthodox methods of treatment in a manner which would have been impossible after legislation imposed stricter professional standards later in the

*Brenda M. White, MA, postgraduate student in the Department of Economic History, University of Glasgow, Glasgow G12 8RT, Scotland.

The material for this paper derives from research carried out in preparation for a doctoral thesis on the subject of nineteenth-century Scottish public health administration under the Police Acts, funded by an SSRC grant, which is gratefully acknowledged.

\footnotetext{
${ }^{1}$ Roberton practised in Edinburgh 1802-10 and London 1810-21.

2 John Roberton, A treatise on medical police, and on diet, regimen, \&c. In which the permanent and regularly recurring causes of disease in general, and those of Edinburgh and London in particular, are described; with a general plan of medical police to obviate them, and a particular one adapted to the local circumstances of these cities, 2 vols., Edinburgh, John Moir, 1809.

This treatise has been described in many publications as "the first notable treatise in English on the subject", viz: George Rosen, 'The fate of the concept of medical police 1780-1890', From medical police to social medicine, New York, Science History Publications, 1974, pp. 142-158; John D. Comrie, History of Scottish medicine, London, Bailliere, Tindall \& Cox, 1927, p. 284; Thomas Ferguson, Dawn of Scottish social welfare, Edinburgh, E. \& S. Livingstone, 1948, p. 240.

${ }^{3}$ Johann Peter Frank, System einer vollständigen medicinischen Polizey, Mannheim, Schwann, $1778-88$. Often translated as $A$ system of medical police.

^Andrew Duncan, Heads of lectures on medical jurisprudence and medical police, Edinburgh, 1801.
} 


\section{Brenda M. White}

nineteenth century. Under scrutiny, Roberton's flamboyant career illustrates the difficulties experienced by unconventional practitioners searching for admission into the medical hierarchy. He emerges as a quick-tempered, quarrelsome, and notorious outsider, seeking patronage by whatever means available, hounded out of Edinburgh and London by respectable established medical figures, and the author of a contemporary bestseller, On the generative system (London 1811), considered by the House of Commons to be an obscene publication. ${ }^{5}$ Moreover, in his fleeting association with medical police he expressed views quite antithetical to Andrew Duncan's interpretation.

\section{MEDICAL POLICE, FRANK, DUNCAN, AND ROBERTON}

The term "medical police" encompasses a surprisingly wide field. Ludmilla Jordanova's work on French medical police identifies four broad meanings: "first, the administration of the health and well-being of the populace as a whole; second, the control of medical practice and practitioners; third, legal medicine, and fourth, the science of hygiene" which, far from indicating confusion and ignorance, "reveals complex debates on the proper role of medical practitioners, their capacity to heal effectively, and their relationship to the people, government and the legal structure."6

The concept of medical police as it developed in Europe in the eighteenth century is expressed most clearly in Frank's Complete system of medical polity. This encyclopaedic work comprehended a continuous study of the life of human beings, beginning before birth and extending to the very end of life. 7 Frank envisaged total state involvement in public health, with strict control over individual liberty where it transgressed state interests: healthy populations for economic and military purposes would be ensured for paternalist despots by state regulations, which, amongst other things, included pre-marital examination, marriage guidance and sex instruction, ante- and post-natal care, provision for foundlings and orphans, the suppression of alcoholism and prostitution, and a comprehensive system of environmental hygiene. Only the control of communicable disease and worker supervision failed to find a place in this unrealized utopia.

Andrew Duncan acknowledged that he imported much of the medical philosophy of Frank's medical police, but he substituted a political framework more suited to Scottish tradition. Duncan accepted from European theory the medical obligation to care for the health and well-being of the whole population, and the training of the medical profession to this end. Unlike Frank, he never envisaged the state intruding upon personal liberties; medical police was to be organized through the activities of private individuals, as an exercise in philanthropy. For Duncan, such philanthropy,

\footnotetext{
${ }^{3}$ This work was one of J. J. Stockdale's publications deemed obscene by the House of Commons. Stockdale was ordered to be imprisoned by the House of Commons in 1838. This led to the case for libel, Stockdale v. Hansard, which changed the rules surrounding Hansard's reporting of Commons' proceedings. See entry for J. Roberton, Lowndes bibliographers' manual, 1857, and entry for J. J. Stockdale in DNB.

'Ludmilla Jordanova, 'Policing public health in France 1780-1815', in Teizo Ogawa (editor), Public health, Tokyo, Taniguchi Foundation, 1981, pp. 12-32.

'Sir John Charles, The social context of medicine (Rock Carling Fellowship lecture, 1962), London, Nuffield Provincial Hospitals Trust, 1962, p. 33.

'Ibid., p. 34.
} 


\section{Medical police: the fate of John Roberton}

whether by medical practitioners or lay people, was an expression of patriotism: the conservation of the human resources of the state, especially during the national emergency of the Napoleonic wars. Medical police was therefore, in Duncan's words, "not merely regarding the welfare of the individual but also the prosperity and security of nations".9 Though his Heads of lectures considered the location of dwelling-houses and hygiene, sanitary measures were far less important to him than the individual care of the sick poor through a system of specialized hospitals and dispensaries, for whose construction and management he gave detailed instructions. ${ }^{10}$ Duncan's work betrays no discontent with the existing traditional system of elementary sanitary provision afforded by the magisterial civic police in Scottish burghs, which was largely confined to street cleansing and the operation of quarantine during epidemics. He believed that doctors trained in the principles of medical police could "give the most judicious advice to the civil magistrate for the prevention of disease" on a consultative basis so that they would "obtain respectability of character rarely to be derived from the cultivation of any profession for mere gain". " Because it interpreted a wider realization of medical police than the later, English-based, sanitary use of the phrase, Duncan's adaptation of Frank's ideals gave Scottish medical police philosophy a particular identity, which profoundly influenced Scottish medical opinion during the Chadwickian debates on sanitary reform in Britain during the 1840 s. ${ }^{12}$

Whereas Frank and Duncan have accessible identities, and recognized professional status, John Roberton has remained a shadowy figure. Hence historians have made assumptions about him based entirely on the Treatise, which is generally regarded by historians of public health and social medicine as a reputable text. Comrie correctly described Roberton as an "Edinburgh general practitioner", ${ }^{13}$ Craig presumed that "Roberton was also a licentiate of the College [of Physicians of Edinburgh] who met with the frustrations known to many pioneers in medicine"; ${ }^{14}$ Crew, acting on

\footnotetext{
'Duncan, op. cit., note 4 above, p. 175.

${ }^{10}$ Ibid., p. 189. These covered site, building, size, staff, and management techniques, and catered for lunatics, the aged, maternity cases, smallpox, and venereal disease. The immediacy of the Napoleonic wars is illustrated by Duncan including the care of prisoners of war alongside civil offenders.

"Ibid., p. 182.

12 From the onset of sanitary agitation in 1839, William Pulteney Alison opposed the popular Chadwickian miasmatic theory of disease. A convinced contagionist, Alison entered the political arena to change the existing Scottish poor law system which, unlike the English system, did not grant relief.as of right. He argued that the destitute state of the Scottish poor contributed more to the rapid spread of disease than dirt did. He attacked the poor laws on medical police grounds: "It is generally admitted in all civilised countries, and indeed is the reason for constituting a separate department of medical instruction under the name of Medical Police, - that the prevention of Disease on a large scale may often be in the power of a community, although beyond the power of many inhabitants composing that community; and the present enquiry is an attempt to apply that principle to the great mass of disease and suffering which springs from poverty and destitution." (W. P. Alison, Observations on the management of the poor in Scotland, Edinburgh, William Blackwood, 1840, p. viii.) Later, in 1848, with the added dimension of medical politics relating to the English-based General Board of Health and its questionable understanding of Scottish conditions, Alison, supported by the powerful Edinburgh Royal College of Physicians, successfully thwarted Chadwick's desire to extend the Health of Towns legislation to cover Scotland.

${ }^{13}$ Comrie, op. cit., note 2 above, p. 284.

14 William S. Craig, History of the Royal College of Physicians of Edinburgh, Oxford, Blackwell Scientific Publications, 1976, pp. 517-518.
} 
Roberton's assumed MD on the title-page of the Treatise, claimed that $\mathrm{Dr}$ Roberton was part of a strong group of extra-mural teachers offering instruction around the university: ${ }^{15}$ while Shryock termed Roberton "a forward looking sanitarian whose ideas made little impression at the time."16

Given the sporadic nature of published references in English to medical police around the turn of the eighteenth century, Roberton's Treatise, written in two volumes with over 700 pages of text to plunder, has been used as a benchmark by historians in describing the onward march of social medicine. But, would it have received the same attention under its originally intended title of Diseases of Edinburgh. In which the sources of the permanent, or regularly recurring diseases of Edinburgh are pointed out, and the entire removal of these sources, as well as a method of cure for the diseases they induce are explained; preceded by a copious introduction, describing the general influence of local circumstances in the generation of disease, and detaining [sic] fully a general plan of medical police?

The Treatise reveals Roberton as a convinced miasmatist who viewed medical police solely in terms of the detection and removal of disease, which he regarded as "the true essence of medical police": a view gained from practice among the Edinburgh poor. Most of the work is taken up with an examination of the natural and artificial causes of disease, the specific diseases caused by failure to attend to these causes, and a "police", or set of regulations for remedial action. To illustrate the need for hygienic principles, Roberton cites numerous examples of current scientific medical thought, quoting from Pringle, Lind, Morveau, Bertholet, and Russell Stranger, from whom he "derived an assistance which it gives me the greatest pleasure to acknowledge". ${ }^{17}$ To illustrate his case for medical police on sanitary grounds, Roberton also includes a large number of geographic and topographic examples, drawn on a global scale, regarding the predisposing factors of disease. However, as they bear no acknowledgement, the reader is led to believe they are Roberton's personal observations whereas in reality there is no evidence to suggest that by 1809 Roberton had left mainland Britain. Whilst the bulk of the Treatise therefore confirms Roberton's eclecticism, it added nothing to the known stock of scientific medical thought.

Other parts of the Treatise that attract the attention of historians are those containing Roberton's views on disease prevention, mainly its last eleven pages. These were radical in the British context because they emphasized state provision of sanitary legislation enforced by a professional corps of medical inspectors. Roberton thought that "A rational plan of medical police cannot be carried into execution without the aid of the legislature."18 $\mathrm{He}$ called for a council of health composed of "some of the principal members of the legislature, some of the chief magistrates of each city and several medical attendants ... who would appoint inspectors of the medical profession

\footnotetext{
is Francis A. E. Crew, 'Social medicine as an academic discipline', in A. Massey (editor), Trends in public health, London, Butterworth, 1949, pp. 46-79.

16 Richard H. Shryock, The development of modern medicine, 2nd ed., Madison, University of Wisconsin Press, 1979, p. 101.

"Roberton, op. cit., note 2 above, vol. 1, p. li.

I Ibid., vol. 2, p. 355.
} 


\section{Medical police: the fate of John Roberton}

whose business it should be, not merely to see whether the rules for the prevention of disease be carried into execution, but whether they be adequate to produce the effect intended." Roberton envisaged a two-fold role for the medical inspectors; therapeutic, the treatment of diseases; and preventative, the superintendence of disease detection, including housing regulation and inspection, environmental hygiene and sewage disposal. ${ }^{19}$ This is interesting for, in Scotland, the latter functions fell increasingly under magisterial police control in large urban police burghs, and produced a sanitary inspectorate independent of the authority of medical officers of health. ${ }^{20} \mathrm{~A}$ similar scheme of sanitary-based functions carried out by medical inspectors was suggested by Chadwick and Rumsey in the 1840s. ${ }^{21}$ As both Crew and Rosen noted, ${ }^{22}$ Roberton seems closer to Frank than to Duncan in his grasp of the social relationships between dirt and disease. However, in the Treatise Roberton makes no reference or acknowledgement to either Frank or Duncan.

Roberton's view of the State's sanitary role adopted a European approach to medical police. As a miasmatist, like many radical thinkers of his time, he wished to remove sources of "putrid emanations", and consequently thought building regulations important, including "the entire destruction of many houses" with government aid to reimburse proprietors, ${ }^{23}$ but, unlike later writers on sanitation such as Chadwick or Rumsey, his suggestions were brief and imprecise. His view of medical police clashed with Duncan's on such fundamentals as hospital provision and the advisory role of the doctor in relation to the civil magistrate: for Roberton, the preventative measures he suggested obviated the need for hospitals and he did not see medical police in the wider sense of, say, the geriatric and psychiatric hospitalized care envisaged by Duncan. ${ }^{24}$ Nor did Roberton agree with Duncan's use of non-medical philanthropic help and tacit acceptance of magisterial police authority in the provision of elementary environmental hygiene (which was to develop into police-controlled nuisance removal and lodging-house inspection in the wake of Chadwickian enquiries). ${ }^{25}$ Roberton's position on the role of the doctor in public health was quite clear even though his suggestions as to its execution were imprecise. His most lucid exposition of the medical role in relation to the other agencies engaged in control of the public health is expressed in the preface to the Treatise, "It ought to be recollected, that it is not the object either of the mere philanthropist, or of the magistrate, to suggest plans for the removal of disease. The former ought pathetically to paint the sufferings of his fellow creatures; the latter ought to execute schemes for

\footnotetext{
19 Ibid., vol. 2, p. 354-357.

${ }^{20}$ For local Police Acts, see below. Cleansing duties evolved into nuisance removal and lodging-house inspection. These duties were carried out by senior police officials because their application infringed private property rights. The later sanitary inspectorates in large burghs carried an executive-level officer who shared equal parity with the Medical Officer of Health in purely sanitary duties related to disease prevention. The therapeutic duties of the MOH remained solely his responsibility.

${ }_{21}^{21}$ Henry W. Rumsey, Essays on state medicine, London, Churchill, 1856, p. 279.

${ }^{22} \mathrm{Crew}$, op. cit., note 15 above; Rosen, op. cit., note 2 above.

${ }^{23}$ Roberton, op. cit., note 2 above, vol. 2, p. 357.

24 Duncan was instrumental in the founding of the Lunatic Asylum in Edinburgh, 1811, and earlier founded the Edinburgh Dispensary through public subscription, 1780.

${ }^{2 s}$ Both Edinburgh and Glasgow incorporated these police functions into their own local Police Acts during the 1840 s.
} 
their relief; but the task itself belongs to the physician." 26

Interesting as these points are to the historian of public health, these sanitary proposals are not the only feature of Roberton's Treatise. Frequently, verses are inserted, and there is a rag-bag mixture of voluminous suggestions on diet and regimen aimed at his middle-class readership. These include hints on waterproofing leather shoes, ${ }^{27}$ dental care, dress, a short history of Edinburgh with comments on current affairs, and Scottish dietary secrets revealing the composition of haggis. ${ }^{28}$ Many of the comments in the preface and conclusion are plainly autobiographical, indicating Roberton's anger at his struggle to gain recognition and status within the medical profession. And, in the body of the Treatise itself, there are examples of character assassination aimed at his "enemies", 29 for Roberton was an avowed Whig. Both the Treatise and his earlier work on the internal use of cantharides ${ }^{30}$ were dedicated to Lord Archibald Hamilton, MP for Lanarkshire, a tireless worker for franchise and burgh reform. There is an abundance of political references in the Treatise which have not previously engaged the attention of medical historians, probably because they often refer to local Edinburgh politics. Underlying all this, discounting the florid prose and the ghastly poetry, there is the sense of frustration identified by Craig. The Treatise was written by an angry man and it is seamed with personal, professional, and political grudges. These parts of the Treatise are as revealing of contemporary medical issues in Edinburgh and London as those that appear to be central to the history of public health. Attention should also be directed to them if Roberton's true significance is to be ascertained.

\section{JOHN ROBERTON}

John Roberton was born in Hamilton, Lanarkshire, in 1776. He was the eldest of four children born to parents of reasonably modest origins in the town, ${ }^{31}$ but little is known of his life until he arrived in Edinburgh at the age of twenty-two in order to follow the profession of surgeon. He registered for one session in the class of Monro tertius, in Anatomy and Surgery in 1799, but did not graduate or continue his university study. As Crew points out, there was a strong group of extra-mural teachers in Edinburgh, and with the separate recognition given to both surgeons and physicians in Edinburgh Roberton could have attended one or more of these classes without recorded evidence of his early career. He was admitted into the prestigious Royal Medical Society in 1798, which suggests an element of patronage, as yet unknown. There is no recorded proof that Roberton gained qualifications of any description or

\footnotetext{
26 Roberton, op. cit., note 2 above, vol. 1, p. xliii.

${ }^{27}$ Ibid., vol. 2, p. 91: 1 pt. Drying Oil, 2 oz Yellow Wax, 2 oz Spirit of Turpentine, $\frac{1}{2}$ oz Burgundy Pitch, melted over a slow fire and rubbed in in stages then allow to dry before wearing.

2 In deference to national feelings readers are directed to any good Scottish cookery book.

20 Throughout his written works, Roberton constantly uses "my enemies" without specific personal references. More often it is used in a party sense, sometimes in a professional context.

${ }^{30}$ A practical treatise on the powers of cantharides when used internally; demonstrated by experiments and observations, in 3 parts; including an enquiry concerning the nature and proper medical treatment of gleet, leucorrhoea and obstinate sores, Edinburgh, 1806.

${ }^{31}$ After discounting Roberton families who were small land-holding farmers around Lanarkshire, the parents of the particular children identified in Hamilton Parish Register appear to have been tradespeople. Roberton's father was probably a younger son of such a family whose land could not support him.
} 


\section{Medical police: the fate of John Roberton}

that he was a licentiate or fellow of either the two Royal Colleges in Edinburgh or the Royal Faculty of Physicians and Surgeons in Glasgow, which were the three Licensing Corporations in Scotland..$^{32}$

The Royal Medical Society was an élite body. Founded in 1734 to debate medical subjects, it required members to present papers on a regular basis for discussion. ${ }^{33}$ Roberton presented papers on catarrh, on blisters and cantharides (Spanish fly) in the cure of disease, opium in certain deaths, and ulcers. ${ }^{34}$ They show no signs of interest in medical police, though it had been the subject of recent lectures by Professor Duncan in the university. These early papers are highly critical of current thought and opinion and foreshadow Roberton's later writings.

Remarks in his published works suggest that Roberton worked under the tuition of an older doctor until 1802, when he appears to have set up as a general practitioner. He then developed a specialism in treating "sexually transmitted diseases" by the internal use of cantharides, better known as Spanish fly, a strong urinary stimulant that was also popularly supposed to be a sexual stimulant; its internal use was frowned upon by most medical practitioners for this reason. ${ }^{33}$ A more conventional use of cantharides was its external application to produce blisters. In 1806, Roberton published a small article in the Edinburgh Medical and Surgical Journal on the use of cantharides. ${ }^{36}$ This received attention outside Scotland, extracts being translated and printed in German and French medical journals. ${ }^{37}$ Roberton then published his first major work, A practical treatise on the powers of cantharides when used internally. ${ }^{38}$ Couched in popular language, it is a literary personal advertisement, with copious case histories giving the interested reader at least one set of circumstances, all sympathetically discussed, with which he, or she, could readily identify. The work, which claimed near-miraculous powers for the internal use of cantharides, also contained scarifying criticism of more established cures and their authors, such as John Hunter.

Publishing as a form of medical self-advertisement was not a novel practice in the eighteenth and early nineteenth centuries, and clearly Roberton, with no connexions in Edinburgh medical circles, university degree, or licence from the Corporations, was a fringe figure depending on some other form of recognition and status with which to enter the medical hierarchy. Commenting on his lone struggle, he wrote, "because of lack of financial and family support my sole dependence therefore rested upon my own industry and unwavering attention to the calling of that profession to which alone

\footnotetext{
${ }^{32}$ All the Scottish university records have been searched. St Andrews, which would grant the degree of MD on evidence of testimonials - a facility which was sometimes abused, - and Aberdeen have no record of Roberton gaining an MD.

${ }^{33}$ William Stroud, History of the Royal Medical Society, Edinburgh, 1834.

34 Royal Medical Society Dissertations, vols. 43, 44, 47.

3s John Gordon Smith, Principles of forensic medicine, London, Underwood, 1821. Smith regarded cantharides as a poison and made specific reference to its supposed properties.

${ }_{36}$ 'Remarks on the internal use of tincture of cantharides in gleet leucorrhoea; illustrated by cases', Edinb. med. surg. J., 1806, 2: 134-144.

${ }^{37}$ See entry for John Roberton, Medicinisches Schriftsteller-Lexicon, Copenhagen, Callisen. 1833, vol. 16, pp. 184-185.

38 Roberton, op. cit., note 30 above.
} 


\section{Brenda M. White}

I had to depend upon for my future comforts in life". ${ }^{39}$ In his search for upward professional mobility, he trod a recognized political path: enrolling as an assistant surgeon in a Volunteer Corps, becoming a member of a Masonic Lodge, gaining a decent address from which to practise, making the acquaintance of the more raffish younger members of the medical establishment, lending money to the impecunious, and ghost-writing articles for the less talented. It was through these dubious connexions that, in 1808, Roberton was caught up in a scandal which delighted Edinburgh for several months. The controversy originated in the obscurities of Masonic rivalries, which rapidly divided along party lines and international jealousies between the Grand Lodges of Scotland and England. Roberton entered the affair in defence of his commanding officer in the Volunteers, a rising Whig lawyer, James Gibson. The scandal assumed preposterous proportions, involving a scurrilous pamphlet and placard war in which many of Roberton's private squabbles surfaced. ${ }^{40}$ These centred on his feud with Dr James Sanders and the disputed authorship of Sanders' recently published work on digitalis. ${ }^{11}$ In a satirical sketch published anonymously as a sequel, Roberton was mercilessly depicted as Dr Bluster whose unorthodox methods of treatment merited libellous ridicule. The sketch also lampooned Roberton's Cantharides as a "quackish attack on public credulity" and, in reference to his recently advertised work in progress, Diseases of Edinburgh, claimed that Roberton (Dr Bluster) "cannot write on the subject he has promised due to his extreme ignorance and his incapability to publish". ${ }^{2}$

Roberton had begun Diseases of Edinburgh in 1807 and, although he announced during the 1808 pamphlet war his intention to publish, he never did so. ${ }^{43}$ Diseases of Edinburgh, however, later formed the basis of his Treatise. Many of the furious comments made in its preface reflect these current controversies, Roberton's anger being directed at the real or imagined limitations placed on his professional advancement and the status of his treatment of venereal disease by cantharides. He wrote darkly of the difficulties facing a young physician:

He can, with difficulty, find a patron to his real merit, because none are judges of it but a few of his profession, whose interest it is that it should be concealed. If he attempt to shew the weakness of the fashionable system ... the whole faculty are alarmed, their vanity is piqued in having their opinions,

${ }^{39}$ Letters from Dr Baillie with remarks by John Roberton, London, J. J. Stockdale, 1817, p. 10.

* Though some of these pamphlets are catalogued in the British Library Collection under John Roberton, a more complete bound set is to be found in the National Library of Scotland under 'The Gibson Mitchell Controversy' RY.1.4.215. These were collected by Mr Bridges and bear the information that they were sent to Dr Baillie in London in 1816 at the express request of Andrew Duncan senior. But for Bridges' notation, Duncan's interest in the 1816 quarrel and Roberton's exclusion from London established medicine by Baillie, would never have come to light. It is an example of the Edinburgh-London network which existed to exclude Roberton in 1810 and 1816.

"James Sanders, Inquiry into properties of foxglove and digitalis, Edinburgh, 1808. In the pamphlets, Roberton claimed he had written part of the work. Sanders is quoted in terms of great respect in Roberton's Cantharides (1806), but after the pamphlet war (1808), Sanders withdrew into the established circle of medicine and he and Roberton became bitter enemies. (Sanders was the father of William Rutherford Sanders, Professor of Pathology, Edinburgh, 1869-1881.)

${ }^{42}$ The Scotch diable bioteaux or Asmodeus in Edinburgh, by Zacharia Clearweather, in 'Gibson Mitchell Controversy', op. cit., note $\mathbf{4 0}$ above.

${ }^{43} \mathrm{~A}$ full-page advert for this work in progress was placed in the pamphlet. In defence of Mr Gibson's third charge against Dr Mitchell, by John Roberton, in ibid. 


\section{Medical police: the fate of John Roberton}

which they thought perfectly established, brought into question, and exposed by a young man; and their interest is evidently concerned to crush him as soon as possible. In the meantime, the effect of every deviation which he makes from the common practice is anxiously watched, all his prescriptions must remain on the Apothecaries file to rise in judgment against him .... He has to establish his professional reputation against the malevolent and secret illiberality of those who from selfish motives have anxiously been watching for his fall. 4

This very evident feeling of frustration has been interpreted by historians as relating to Roberton's association with medical police. But when Roberton wrote these comments, he was, more likely, referring directly to cantharides as he had only recently become interested in medical police. A further example in the Treatise of Roberton's current preoccupation with his personal vendettas is his vicious, anonymous attack on Dr James Sanders and his writings. "I must beg also that his trash may not be imputed to me"4s is among its mellower sentiments.

In the period between 1808, when Diseases of Edinburgh was still in preparation, and 1809, when the Treatise was published, Roberton visited London, perhaps with a view to setting up in practice there. On his return, he incorporated the sections relating to London into his work in progress, expanded the material, and approached John Moir, the Edinburgh publisher, with his restyled work, $A$ treatise on medical police, and on diet, regimen $\& c$., a title of sufficient topical interest to warrant publication.

The 1809 edition of the Treatise is curious in that, for some reason best known to himself, Roberton styled himself MD and sent complimentary copies to numerous prominent members of professional Edinburgh society. The work was then withdrawn and the title-page reset to present Roberton under his usual designation, surgeon. The early copies carried an advertisement for a forthcoming new work on the topic of medical police in the form of a small pamphlet on simple and useful rules for the preservation of health for the lower orders of society, and Roberton promised to donate the pamphlet's proceeds to the fund for the proposed Edinburgh Lunatic Asylum. The Asylum was the project of Andrew Duncan and formed a practical illustration of his university teachings. If this was an attempt to mollify Duncan, then it was a clumsy one. In any event, the advertisement was dropped from the subsequent pressings and the pamphlet was never written. In the absence of any hard evidence as to how the Treatise was received, these are small pointers to the difficult times Roberton experienced from its publication in late 1809 to his hasty departure from Edinburgh in June of 1810 . His departure was precipitated by his own temperament but perhaps engineered by his "enemies".

Roberton was still a member of the Royal Medical Society, which annually elected four presidents during April. They were chosen mainly for their debating skills and very few failed to distinguish themselves in professional life. ${ }^{46}$ James Sanders stood as $^{\circ}$ a candidate in 1810 , and Roberton, carrying on his personal feud, decided to stand against him. Sanders was elected and Roberton was accused of writing obscene epithets on the voting papers, and of writing "highly indecent, disrespectful and

\footnotetext{
Roberton, op. cit., note 2 above, vol. 1, pp. xxvii-xl.

4s Ibid., vol. 1, pp. 239-241, footnotes, gives references to recent stringent review of Sanders' Digitalis in Critical Review, March 1808.

* The life of Sir Robert Christison, Bart., (professor of medical jurisprudence and medical police 1822-32) edited by his sons, 2 vols., Edinburgh, William Blackwood, 1885, p. 52.
} 
disgraceful letters" to the Society. ${ }^{47}$ These formal charges occasioned a specially convened meeting of the Society, at which Roberton was found guilty by a majority of 58 to 6. He was ignominiously expelled from the Society, narrowly escaping a vote for his public condemnation in the press. ${ }^{48}$ Roberton was only the third Society member to be expelled since its establishment in $1734.4^{9} \mathrm{His}$ expulsion effectively closed the doors of Edinburgh medicine in his face, and signalled his departure for London.

Roberton was already engaged in writing his most widely published work, On the generative system, ${ }^{30}$ when the Treatise went to press. He then wrote to Matthew Baillie in London asking him to accept the dedication of the partially completed book. Baillie was himself a Lanarkshire man, the son of a notable clergyman, and had spent the best part of his youth in Roberton's native Hamilton, a fact to which Roberton drew Baillie's attention. But, it was not just that tenuous connexion which drew Roberton to beg Baillie's patronage. Matthew Baillie MD had recently been appointed Physician to the King. He was also the doyen of the Scottish medical fraternity practising in London, a position he inherited as the chief beneficiary of his uncle, the celebrated William Hunter. Though Scottish physicians appointed to the Crown were not unusual, there was considerable dispute in London on the merits of Scottish medical qualifications. ${ }^{31}$ Baillie's patronage was therefore essential to Roberton's London career prospects. ${ }^{32}$ However, from the outset Roberton fell foul of his intended patron, for On the generative system severely criticized methods used by Sir Everard Home in his treatment for stricture of the urethra. Home was related by marriage to Baillie, who objected to his relative's inclusion in Roberton's book unless the observations were made "in the spirit of liberality and candour". Correspondence, which Baillie later regretted, more especially that addressed from Windsor Palace, passed between Roberton and his now unwilling patron. Though Baillie successfully restrained Roberton from publishing the correspondence in the first three editions of the Generative system, Roberton prefaced the work with one of his own letters to Baillie. ${ }^{53}$ Roberton had difficulty in finding a publisher but, in 1811 , it was taken up by the controversial publishing house, J. J. Stockdale of Pall Mall. ${ }^{54}$ As with Cantharides, Roberton's Generative system made no claims to be a scientific work. The author stated "In this work, no tedious, uninteresting investigation will be entered into; it will be purely practical and suited to readers in general", but later he claimed

${ }^{47}$ Minutes of Royal Medical Society, 6 April 1810.

4 Ibid., 11 April 1810.

49 According to Stroud, op. cit., note 33 above, only two others were expelled, one for debt, the other for non-attendance.

so John Roberton, On the generative system, being an anatomical and physiological sketch of the parts of generation and a treatise on their diseases viz. gonorrhoea, gleet, lues venerea, strictures and other morbid affections of the bladder, urethra, seminal vessels, etc., London, J. J. Stockdale, 1811.

"11 For a detailed account of this controversial subject read David Hamilton, The healers, Edinburgh, Canongate, 1981, pp. 139-145.

32 This facet of Baillie is pointed out by his biographer "Dr Baillie was also remarkable for the consideration he paid to the feelings of his professional brethren, more particularly to the younger branches and others who could not be supposed to enjoy the full confidence of the public". J. Wardrop, The works of Matthew Baillie MD, London, Longman, 1825, p. xli.

${ }_{33}$ Roberton removed the first part of his letter to Dr Baillie, which avoided reference to Baillie's criticism of him.

${ }^{34}$ See entries for J. Stockdale and J. J. Stockdale in the DNB for details of their libel suits. 


\section{Medical police: the fate of John Roberton}

that it was written "solely for the use and altogether for the perusal of the medical profession."'ss It followed the pattern set by Cantharides and, in typical Roberton style, was scattered with strong criticisms of Cullen, Hunter, and Abernethy, and devoted a chapter entirely to the excoriation of the unfortunate Sir Everard Home. Its twelve extremely detailed illustrations of the genitalia made it a runaway success, and it passed into a second edition in 1812. In that same year, Stockdale reprinted Medical police and, in 1813, Roberton's Complaints peculiar to the female, which consisted of material extracted from Cantharides and the Generative system.

In 1816, the Generative system went into a third edition enlarged by the addition of correspondence between Roberton and Colonel Sir Henry Torrens of the Army Medical Board. ${ }^{36}$ In several letters to the Duke of York and the Army Medical Board, Roberton claimed that returning servicemen had increased the prevalence of venereal disease and suggested specialist hospitals to treat those affected. "Lock hospitals", he wrote, "are not good as they exclude a greater part of those suffering under chronic complaints and the lower orders are wary of public hospitals as they fear that they might be experimented upon ... to them dispensaries are particularly adapted." Replying for the Duke of York and the Board, Torrens stated that the general hospitals were doing sufficiently well in the diseases referred to and he could see no possible reason to promote a specialist hospital. This notoriety, vaguely connected to the Royal Family through the Duke of York, brought the book to the notice of $\mathrm{Dr}$ Baillie, the King's Physician, to whom the work was dedicated, forcing him to publish a public disclaimer. In an open letter in Bell's Weekly Messenger, May 1816, Baillie wrote, "I shall not express what I think of Dr Roberton's conduct in prefixing my name to an obscene book, without my knowledge; but from the obscenity itself, he has forfeited his rank and character in society. I am anxious, however, to preserve mine ... I did not know there was an either a second or third edition of this book till my friend shewed me the third edition and that I even thought $\mathrm{Dr}$ Roberton had been dead for the last two years." 37 Baillie was doubtless referring to a simple, but erroneous, insertion in the Gentleman's Magazine, September 1814: "Fell down dead on going into his lodgings in St James Park, Dr John Roberton. Author of the work On the Use of Cantharides." 8 But, unhappily for Baillie, Roberton was alive. In 1817, the Generative system went into a fourth edition, this time prefaced by the acrimonious correspondence with Baillie, which was also published in pamphlet form as Letters from Dr Baillie with remarks by John Roberton.

After 1817, Roberton slipped from sight, despised and discredited by the medical establishments of Edinburgh and London, yet probably surviving the experience quite comfortably on the proceeds of the Generative system and his private practice. His address in 1817 was still St James's Park, which suggests more than an element of success and is perhaps indicative of the degree of prosperity that some unlicensed practitioners could achieve prior to the Medical Act. Research to date has not

ss Letters from Dr Baillie ..., op. cit., note 39 above, p. 26.

s6 Roberton, op. cit., note 50 above, 3rd ed., 1816, pp. 536-548.

"Letters from Dr Baillie, op. cit., note 39 above, pp. 18-19.

so Gentlemen's Magazine, September 1814, 11: 300. It has not been established whether this was a hoax played on Roberton or an attempt by him to avoid creditors. 
identified any further reference to Roberton in Britain, though it is thought that he was the author of pseudo-medical erotica written for J. J. Stockdale under the penname of T. Bell MD, the best known of these being Kalogynomia, or, the laws of feminine beauty (1821). ${ }^{59}$

\section{POLITICS, MEDICAL JURISPRUDENCE AND MEDICAL POLICE, AND POLICE}

When it is considered that Roberton's overwhelming preoccupation lay elsewhere in medical treatment, his brief venture into medical police is puzzling. An explanation may be found if we consider the timing of the Treatise and its relationship to contemporary debates on the medical practitioner's relationship to the people, government, and the legal structure.

As they emerged in Scotland, medical police and its senior partner, medical jurisprudence, took on an acutely political nature. The new regius chairs at Edinburgh in 1807 and Glasgow in 1839 were closely connected to the Whig cause and were opposed by the Tory party..$^{60}$ When Roberton began to write Diseases of Edinburgh in 1807, he did so during politically explosive years in Britain. 1806 saw Fox's short-lived ministry installed and, for a brief period in an era of solid Tory dominance, many Whig hopes were revived, including an interest, derived from French revolutionary models, in criminology and the penal system. In Scotland, this interest bore immediate fruit through the intervention of Henry Erskine, the newly appointed Whig Lord Advocate for Scotland, whose egalitarian principles were closely connected with the Friends of the People. ${ }^{61}$ Erskine, a lifelong friend of Andrew Duncan, ${ }^{62}$ effectively supported Duncan's long campaign to institute a chair of medical jurisprudence and medical police. Duncan had begun lectures on medical jurisprudence earlier, in the 1790s, publishing Heads of lectures on medical jurisprudence in 1792. The lectures were incorporated into those given under the institutes of medicine, and Duncan added medical police lectures after 1795. In 1798, he addressed a memorial to the patrons of the University (Edinburgh Town Council) on the importance of medical jurisprudence in medical education and the need to institute a chair. ${ }^{63}$ The extremely Tory-dominated Town Council and the university professoriate refused Duncan's application on the grounds that the subject of medical jurisprudence and police had no obvious importance and held no promise of advancing the prosperity or dignity of the

\footnotetext{
59 Lowndes, op. cit., note 5 above.

${ }^{\infty}$ The Edinburgh chair is discussed below. The Glasgow chair, a direct Whig appointment of Robert Cowan by Lord John Russell was vigorously opposed by the Senate who already had their own candidate to be appointed under the university patronage. Cowan died in 1841, and his successor, Harry Rainey, was a Tory political appointment. See Lancet, August 1839, for this controversy; also James Coutts, History of the University of Glasgow, Glasgow, MacLehose, 1909, pp. 538-541. Rainey developed the jurisprudence aspect of the chair at the expense of the medical police content. The latter received no mention in his lecture prospectus, Syllabus of lectures on forensic medicine, Glasgow University Press, 1868, which is interesting because William Tennant Gairdner, professor of medicine (practice of physic) at the University, was also the first part-time Medical Officer of Health of Glasgow, 1863-1872, and was delivering lectures in hygiene at the university.

${ }^{61}$ Alex. Fergusson, Henry Erskine, his kinsfolk and times, Edinburgh, William Blackwood, 1882, p. 329.

62 Ibid., p. 63, "He [professor Duncan] took the utmost pride in the friendship of Mr Erskine and lost no opportunity of referring to their intimacy". Erskine was also deeply committed to Duncan's Dispensary and Asylum, being on the board of governors for both.

${ }^{63}$ University Senate Minutes, vol. 2, pp. 146-147.
} 
university. ${ }^{64}$ Undeterred, Duncan then issued for public circulation his Heads of lectures on medical jurisprudence and medical police in 1801, continuing his lectures meantime.

Medical jurisprudence, which formed the basis of modern forensic medicine, attempted to provide a scientific basis for legal investigations where medical expertise was relevant. This not only included the detection of homicide, but also matters closer to the interests of property. Erskine made special reference to the mental fitness of testators disposing property under the Scottish law of deathbed when supporting Duncan's appeal for the establishment of the chair of medical jurisprudence and medical police. Erskine and Duncan were both impressed by François E. Fodéré's Les lois éclairées par les sciences physiques, ou traité de médecine légale et hygiène publique (3 vols., Paris, an VII [1799]), which dealt with many of the subjects taught by Duncan in his lectures on juridical medicine; and the work itself was specifically referred to by Erskine in his support for Duncan. ${ }^{65}$ That a French law text should be so attractive to the Scots is easily explained by the shared basis of the French and Scottish legal systems in Roman law. In Scotland, medical jurisprudence and medical police retained their joint position until the end of the nineteenth century, when separate chairs of hygiene were established. ${ }^{66}$

The establishment of the Edinburgh regius chair in medical jurisprudence and medical police by the Whig administration in 1807 circumvented the university patrons. Political change therefore promoted Duncan's teaching of medical police, and through Erskine's powerful family connexions ${ }^{67}$ the subject, by its link with the legal need for medical jurisprudence, withstood the attempts of the returned Tory administration to overturn it in $1807 . .^{68}$ However, the medical faculty was not anxious to house the new chair: it was not taken into the faculty of medicine until 1833, and remained an optional subject for both legal and medical students until that date. ${ }^{69} \mathrm{It}$ was placed within the faculty of law, and lectures were stringently restricted to "those branches of medical science serving to promote the administration of justice ... and

\footnotetext{
64 Ibid., p. 148.

${ }^{65}$ Copy of memorial presented to Patrons of Edinburgh University, Dr Duncan Snr and Hon. H. Erskine, Lord Advocate, 1806.

* Medical Officers of Health were first appointed in Scotland, under Police Acts, for Edinburgh, Aberdeen, and Glasgow in 1862/3. All were university based; Henry Littlejohn lectured in medical jurisprudence and police at Edinburgh; Frances Ogsten was Professor of Medical jurisprudence and police at Aberdeen; William T. Gairdner, see note 60 above. All were part-time appointments.

${ }^{67}$ Henry Erskine was the second son of the Earl of Buchan, Cousin to the Earl of Mar, brother to Thomas Erskine, Lord Chancellor of England.

For a detailed description of this see Rumsey, op. cit., note 21 above, p. 67.

- Despite consistent applications for inclusion into the medical faculty by each holder of the chair (Andrew Duncan jr, 1807-1819, William Pulteney Alison 1819-1821 and Robert Christison 1822-32), the faculty refused to admit the subject. In 1824, Christison addressed a strong Memorandum to the principal and professors of the University of Edinburgh complaining about its optional status and the deleterious effect this had on the professorship, holders of the chair received only $£ 100$ pa from the civil establishment and, as few students took up the option, fees were negligible. As part of the cholera precautions, the Royal College of Surgeons of Edinburgh made a course of medical jurisprudence and police mandatory for their Diploma from 1829, and in 1833 it was admitted into the faculty of medicine for, "Medical Jurisprudence has now become so important a study and is required by so many of the inferior Boards of Medical education, that its exclusion from a course of study, in a university where it is so well taught, would have been deplorable." (Edinb. med. surg. J., 1833, no. 18.)
} 


\section{Brenda M. White}

matters connected with the preservation and improvement of the public health". ${ }^{70}$

The management of rapidly changing urban conditions had also engaged the attention of local civic authorities in Scotland. Quite apart from the greater opportunities and motives for civil crime, an increase in population brought with it a need for regulated control of public amenities such as the cleansing, lighting, and paving of streets. Throughout the nineteenth century in Scotland, this was accomplished by local and general Police Acts.

The word "police", which was in this Scottish context borrowed in the eighteenth century from France, was not applied solely to the control of crime, as it was in the late nineteenth- and twentieth-century interpretations, but was used to describe regulatory functions of local government. By the mid-1770s, these had deteriorated into the provision of street and market hygiene and were so recognized by contemporary observers. Adam Smith in 1763 remarked that "police" now only related to "the inferior parts of [civic] government, viz:- cleanliness". the eighteenth century, the provisions of lighting and paving the streets were added to the police functions of local town councils. Thus the term "a system of police", by 1800 , covered far more than the criminal police duties. This is nicely expressed by Denholm, writing on the first Glasgow Police Act, 1800: "From the state of society, it becomes necessary in every large city, or particular district, that a set of regulations ... should be enacted for its internal government .... In the principal cities of Europe, regulations of this kind, called a system of Police, have long been established .... The city [Glasgow], daily increasing in size and population, and consequently irregularities of every kind becoming more frequent, it was seen that such a set of regulations must be adopted."12

But large urban burghs and cities like Edinburgh and Glasgow had outgrown the ability of the old town councils to impose sufficient local taxation to fund necessary improvements. By 1800, the revolutions in America and France had produced a certain independence of spirit among local taxable populations, and they were reluctant to part with their money unless they had some control over civic expenditure. Consequently, Police Acts established in Scotland the popular election of police commissioners by rate-paying property holders. ${ }^{73}$ Candidates for election were usually required to hold property above a $£ 15$ yearly rental valuation and the franchise was set at $£ 10 .{ }^{14}$ Cities were divided into wards, and a commissioner was elected from each ward. The Police of a city was then placed under the Provost, Magistrates, Baillies, Dean of Guild, Deacon Convenor, and the elected police commissioners, who were given powers to levy police rates to finance improvements. Commissioners

\footnotetext{
10 Warrant for Andrew Duncan, Junior, appointment as Regius Professor of medical jurisprudence and medical police. University Senate Minutes, vol. 2, p. $430-434$.

"Adam Smith, Lectures on justice, police, revenue and arms, delivered at the University of Glasgow, 1763, edited by E. Cannan, Oxford, Clarendon Press, 1896.

12 James Denholm, The history of the city of Glasgow and suburbs, 3rd ed., Glasgow, R. Chapman, 1804, pp. 294-295.

13 These democratically elected Commissioners and the "Police system" have been described as "a small but growing democratic enclave surrounded by irresponsible oligarchy". William Ferguson, Scotland. 1689 to the present, Edinburgh and London, Oliver \& Boyd, 1968, p. 283.

${ }^{74}$ Ballots were not secret: ballot papers were usually required to bear the name and voting qualification of the elector in addition to those of the chosen candidate.
} 


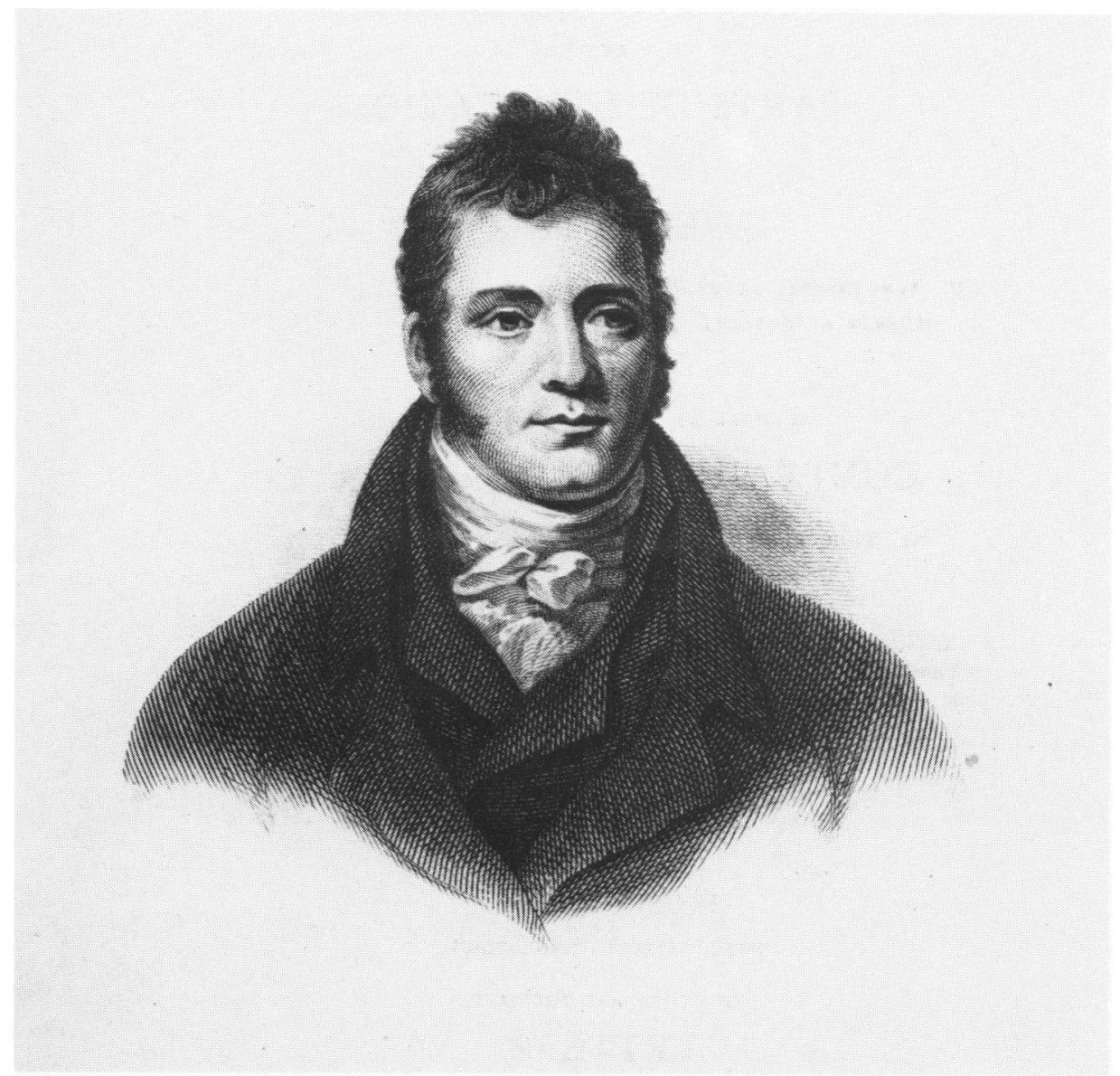

John Roberton. From an engraving by Saxon, in Roberton, On the generative system, 4th ed., 1817. 


\section{Medical police: the fate of John Roberton}

usually served a three-year term, one-third being elected each year. The Police Acts also established paid public offices such as Police Captain, Treasurer, and Clerk, the forerunners of later public offices of Chief Constables, Surveyors, and Masters of Works. It was through the provisions of the Police Acts covering Scottish urban burghs that the traditional town council role of providing elementary street hygiene and the removal of some nuisances under certain conditions, was formalized as a magisterial, or civil, police function.

The first Police Act to cover the city of Edinburgh was passed in 1805. If we consider also that the regius chair of medical jurisprudence and police was established in 1807, the degree of social management under the medical and magisterial use of the word police must have made that word in Edinburgh, in those years, not only controversial but commonplace, especially amongst professional society. Against that background, Roberton began to write the Diseases of Edinburgh, later transformed into the Treatise.

The genesis of Roberton's Treatise may therefore lie in immediate local circumstances: a view substantiated by the inclusion of Edinburgh material throughout the work. Possibly Roberton as a practical man was voicing opinions from a school of thought on medical police opposed to that expressed in Duncan's academic teaching. The career prospects in Roberton's proposed medical force of preventative inspectors may have carried a personal consideration. A similar scheme operated successfully in France using semi-qualified practitioners (officiers de santé); ${ }^{75}$ Roberton would himself have come under this category. Conversely, taking into account the tribulations Roberton encountered during its gestation, and his subsequent move to London, the Treatise can be viewed as a valedictory address to one capital and a calling card on another in which old scores were settled and new horizons anticipated.

Whatever reasons lay behind Roberton's foray into medical police, his proposals for medical superintendence of state sanitary legislation covering personal and environmental hygiene must have been highly unwelcome to Duncan and Erskine, whose main desiderata for the newly established chair were caution and protection. Apart from opposing Duncan's basic principles of medical police, Roberton's proposals attacked the newly acquired authority of local Scottish police establishments. State legislation would supersede their primitive sanitary functions; his housing and building regulations would infringe the traditional local powers of the Scottish Dean of Guild Courts, which were being incorporated into police establishments under the local Police Acts. Ironically, however valid Roberton's views on medical police may seem to historians, he was, in contemporary terms, too late to alter the course of Scottish public health development. The pattern of confining medical authority to therapeutics and expanding magisterial involvement in prevention was already set in Duncan's ideology. Duncan's emphasis on the individual care of the sick poor within the community, his acceptance of magisterial authority in elementary sanitary provision, and his relegation of doctors to an advisory capacity

\footnotetext{
75 For details, see Robert Heller, 'Officiers de santé, second-class doctors of nineteenth-century France', Med. Hist., 1978, 22: 25-43.
} 


\section{Brenda M. White}

endured because of majority approval within the profession. It created a pattern sufficiently entrenched to withstand Chadwick's English-based public health legislation in 1848, and one which remained unbroken in some Scottish police burghs until the twentieth century. ${ }^{76}$ It was a system from which historians of British social medicine may discern an early model of the present separation of community medicine and environmental health. It is precisely this which should make Roberton and his Treatise not only interesting, but significant, to the historian of public health and social medicine.

But Roberton's professional life stands in its own right. His career, like a pin-ball run in a darkened arcade, illuminates brief, random patches of social history related to medicine and the nature of the medical hierarchy before the Medical Act. In an uncharacteristic but prophetic paragraph in his letters to Baillie, Roberton wrote, "Possessing, perhaps, less vanity than falls to the common lot of man, I do not calculate on posterity's taking much trouble about me or my exertions." "n

Posterity did remember Roberton. This study has attempted a contribution towards a wider knowledge of the extent of his exertions.

${ }^{76}$ Glasgow, for instance, retained equal parity between its medical and sanitary executive officers (the Medical Officer of Health and the Chief Sanitary Inspector) until 1920: when the city's Sanitary Department metamorphosed into the Public Health Department headed by the MOH and the office of CSI was completely abolished. It was re-introduced in the 1960 s in preparation for the division of local authority public health into the components of community medicine and environmental health, when the office of MOH was abolished, and the CSI became the Director of Environmental Health for Glasgow.

${ }^{7}$ Letters to Dr Baillie, op. cit., note 39 above, p. 30. 